til at realisere det gode, da den skaber vished om, at en sådan virkeliggørelse er mulig. Også her følger Jørgensen os gennem idéhistoriens fortolkning af skønhedserfaringens forandrende karakter, begyndende hos Platon og frem til Heidegger, Benjamin og Gadamer. De sidstnæunte tematiserer den forandring, skønhedserfaringen foranlediger, som en stræbende proces. Skønhedserfaringen begribes som en processuel begivenhed, hvor det skønne, i den tid erfaringen står på, finder bo i subjektet. Herudfra mener Jørgensen, at skønhedserfaringens forandrende karakter består i, at den åbner det formålsrettede perspektiv mod en bredere horisont, der lader det betragtede være, hvad det er, ikke i sig selv (Jørgensen forestiller sig ikke, at vi erkender transcendente ideer), men i sit samspil med den livgivende opmærksomhed en bredere horisont tildeler. Dette samspil kan også betegnes som en fælles væren, en fornemmelse af en meningsfuld sammenhæng, som med Jørgensen: "vækker det afgrundsdybe spørgsmål om, hvad mening overhovedet er, samtidigt med at den sætter verdens meningsløshed i kritisk perspektiv".

Med en parafrasering af Lukács udtrykker Jørgensens essays sanseerfaringer, ikke af fænomenerne, men af formerne i et samspil mellem hjerteblod og tænkningens klarhed.

Jørgensens hjerteblod er af så høj en temperatur, at det heldigvis præger hendes tænkning. Et sted i bogen beskriver hun en af sine egne skøn- hedserfaringer med ordene: "Jeg var i himlen, som jeg betragtede, og dog samtidigt på altanen, hvor jeg så samme himmel smile forunderligt til mig i min opmærksomhed". I en verden, hvor meget få ser skævt til forskning blottet for hjerteblod, er det modige og ambitiøse formuleringer, der let kan affejes som pladder-romantisk uendelighedslængsel og fantasier om en bedre verden. Men egentligt kun, hvis man ved meget lidt om romantikken og afgjort kun indtil man læser Jørgensens bog. Skonhed - En engel gik forbi forsøger at begribe skønhedserfaringens struktur med stadig reference til ideen, som den udspringer af erfaringen. Jørgensens hjerteblod er formentligt katalysator for hendes tænkning, men hun vil til enhver tid give Hegel ret i, at "die Wärme des Bluts macht's nicht allein". Der er fuldt filosofisk belæg for hver en dråbe. Tilbage er det kun at sige: Læs bogen - den er et must have for visdomsstræbere!

Gitte Tofterup

\section{En indlejret utopi}

David Held: Kosmopolitik. Essays. Tekstudvalg og introduktion ved Mikkel Thorup, Aarbus Universitetforlag, 2006, 402 sider, $348 \mathrm{kr}$.

Kosmopolitik er en samling med essays og interview (fra 1992 frem til 2004) af og med den engelske sam- 
fundstænker David Held. Udvalget har idéhistorikeren Mikkel Thorup stået for, og han har også skrevet en kort introduktion. Her identificerer han blandt andet fire faser i Helds forfatterskab: 1) en kritisk reception af Frankfurter-skolen, 2) en historisksociologisk fase med undersøgelser af blandt andet statens historie, 3) en demokratiteoretisk fase og endelig 4) en globaliseringsteoretisk fase. I bogens essays er det ikke henvisninger til Frankfurter-skolen som sprænger i øjnene. Til gengæld er der mange overvejelser af såvel historisk-sociologisk art som af demokratiteoretisk tilsnit - udover selvfølgelig globaliseringsteori. Jeg vil undervejs søge at pege på hvor disse faser kan siges at have betydning for Helds nuværende tanker.

Held efterlyser en udvikling af "nye normative ressourcer, nye normative begreber" (s. 164), idet han mener at de gamle ideologier, liberalisme og statssocialisme, er forældede. Her får de demokratiteoretiske indsigter han har med i bagagen i høj grad betydning som baggrund for fremstillingen af de normative ressourcer. Han ser det som den politiske teoretikers opgave "at gentænke og skabe nye politiske begreber, der er anvendelige på verden i dag." (s. 163) Det er om noget forfølgelsen af denne ambition der løber som den røde tråd igennem bogen. Det samlende normative begreb er kosmopolitisme. Det opfattes som et begreb der beskriver nogle faktisk foreliggende mønstre af poli- tiske relationer og processer.

Helds opfattelse af utopiens betydning er et frugtbart udgangspunkt for forståelsen af hans teoretiske projekt. Det bliver nemlig helt afgørende for i hvilken retning en global politisk orden bør udvikles. Et sted omtaler han således et sådant forehavende som en 'indlejret utopisme': "For at utopien kan være indlejret, må den forbindes med eksisterende mønstre og bevægelser." (s. 114) Det er således karakteristisk når han siger, at "kosmopolitiske principper ikke [er] principper for et fjernt utopia" (s. 241).

Held holder fast $\mathrm{i}$ at fokusere på de reelle forbedringer gennem eksisterende institutioner, hvilket gør at hans normative ideal er af en art som ligger et godt stykke fra hvad man vel normalt forstår som utopi. Han bruger da heller ikke ordet ofte. Men han er meget opmærksom på, at en teori, for at være normativ, må være mere end en bekræftelse af de eksisterende forhold. I stedet må disse forhold "vurderes i forhold til standarder, kriterier og principper. Disse må [...] komme fra en teori om demokratiet" (s. 114).

I bogen repræsenterer Paul Hirst, $i$ et dobbeltinterview med Held, en mere skarp kritik. Han peger på at "tredive til femogtredive tusind børn dør hver dag af fattigdom, fejlernæring og beslægtede sygdomme" og understreger pointen med følgende korte udsagn: "Ulighed dræber" (s. 341). At der er strukturer og magtforhold som opretholder denne tingenes tilstand, synes jeg ikke Held ofrer til- 
strækkelig opmærksomhed. Hvilket ikke betyder at han ikke er klar over nødvendigheden af $\mathrm{fx}$ at regulere den økonomiske globalisering - problemet er, at det han ønsker mere ligner justeringer end grundlæggende ændringer. I stedet for at fastholde at verden fordrer kritik, vælger han at fokusere på, at det kan blive meget bedre, og nedtoner derved problemerne. "Pauls [Paul Hirsts] pessimisme bygger på en nøgtern vurdering af de politiske udviklinger. Men de fleste af fortidens vigtige politiske innovationer blev opnået på baggrund af håbløse udgangsbetingelser." (s. 345)

I forlængelse af denne tilgang ser han problemerne $\mathrm{i}$ forhold til EU som noget, der kan løses gennem en udvidet demokratisering. Her får jeg en mistanke om, at Held, selvom han anerkender, at magtpolitik er helt centralt for international politik (s. 244), undervurdere den rolle som især pengeinteresser og geopolitiske ambitioner spiller for $\mathrm{fx}$ EU $\mathrm{i}$ forhold til fastholdelsen af den globale fordelingssituation og som en antidemokratisk kraft. Den udbredte frygt for hvad der vil ske, hvis man griber ind overfor markedskræfterne, imødegår Held ved at påpege, at "modstand kræver nye former for politik og ikke bare fremhævelse af de gamle formers robusthed" (s. 324).

Alligevel kommer Held både til at underspille nødvendigheden af en radikal samfundskritik og til at være tavs om hvilke sociale kræfter, der kan og vil kæmpe for forandringerne.
Spørgsmålet til en politisk teori er ikke om den skal være optimistisk eller pessimistisk. Spørgsmålet er snarere hvordan man kan levere en nøgtern kritik, der har blik for både det der fremmer og det der hæmmer virkeliggørelsen af visionen for et bedre samfund.

Held diagnosticerer den nuværende globalisering som en vigtig overgangsepoke, hvor suverænitetsformerne er under forandring. Her viser der sig en række indsigter som formodentlig stammer fra både de historiske-sociologiske og de globaliseringsteoretiske studier. Held peger på, at globaliseringsdebatten i høj grad er foregået mellem to lejre, hvor man på den ene side finder superglobalister, som hævder at vi ser noget helt nyt og epokegørende, mens man på den anden side har skeptikerne som peger på, at der i mange hundrede år har foregået en globalisering, og at der derfor ikke er noget fundamentalt nyt i gang. Det nok vigtigste stridspunkt er om nationalstaten fortsat er den centrale politiske aktør (skeptikerne) eller om staten har udspillet sin rolle (globalisterne). Her indtager Held en mellemposition. Han medgiver skeptikerne, at der i hundreder af år har været tale om forskellige former for globalisering, lige fra udbredelsen af verdensreligionerne over opdagelsesrejsernes tid frem til kolonialismen og endelig den aktuelle form for globalisering. Men Held mener, at der er så mange specifikke træk for denne form for globalisering, at der er tale 
om noget nyt.

Helt centralt er, ifølge Held, at der i dag er tale om 'overlappende skæbnefællesskaber' (s. 217). De omfatter blandt andet de globale miljøproblemer, sygdomsepidemier og spørgsmålet om sikkerhed. Disse spørgsmål, rejst af globaliseringen, skaber "en politisk legitimitetskrise, der er opstået ud fra en uoverensstemmelse mellem en globaliseret verden på den ene side og nationalt opdelte politiske enheder på den anden" (s. 345f). Denne krise mener Held at kunne neutralisere ved at fremme en kosmopolitisk dagsorden.

En nærmere bestemmelse af den historiske baggrund for det kosmopolitiske projekt og dets indhold giver Held i artiklen "Staters ret, Menneskers ret: tre suverænitetsmodeller". De to suverænitetsmodeller som har været fremherskende indtil nu er det Held kalder den klassiske og den liberale suverænitetsmodel. Den klassiske model bygger på tanker hos Bodin om suverænitet og de forståelser af international ret som man forbinder med den Westfalske fred i 1648. Der er i dag stadig elementer i det internationale system, som vi kender fra denne orden. Held påpeger, at den liberale model har været fremherskende siden afslutningen af anden verdenskrig. Der er tale om en suverænitetsform karakteriseret ved, at "effektiv magt udfordres af princippet om, at selvbestemmelse, demokrati og menneskerettigheder er det rette grundlag for suverænitet" (s. 252). Her kommer forskellige internationalt accepterede rettigheder til at spille en væsentlig rolle. Denne udvikling fører i retning af at "grænserne mellem stater, nationer og samfund ikke længere [kan] påberåbe sig den dybe moralske eller retslige betydning de havde i det klassiske suverænitetsregime" (s. 278). Her kommer den suverænitetsform, kosmopolitismen, som Held hævder, vil afløse de gamle, til syne. Det bliver ud fra universelle standarder, at individets rettigheder bestemmes: "Heraf følger også, at medlemskab i eller geografisk nærhed til et politisk fællesskab ikke er grundlag for moralske privilegier. Elementerne er på plads for ikke bare en liberal, men for en kosmopolitisk international ret" (s. 279).

Her ser man en række træk af den indlejrede utopi Held arbejder med. Den er på den ene side et moralsk og politisk synspunkt, og på den anden side er den et projekt, der bygger videre på institutioner som findes eller er under udvikling. Statssuveræniteten er allerede ændret på en lang række punkter, hvilket gør, at Held mener, at det liberale suverænitetsregime står overfor en række dilemmaer og problemer, som udgør "kosmopolitismens omstændigheder" (s. 284 - udtrykket er hentet fra J. Waldron).

Kosmopolitismen har fire forskellige dimensioner: Retslig kosmopolitisme, politisk kosmopolitisme, økonomisk kosmopolitisme og kulturel kosmopolitisme. Held har en række forslag til rettigheder og andre tiltag, 
der er skal til for at virkeliggøre den kosmopolitiske utopi. Der er for det meste tale om ret generelle og teoretiske bestemmelser af disse mål. Men man får dog et rimeligt klart billede af $i$ hvilken retning de forskellige niveauer af kosmopolitisme bør udvikles, hvis Held skulle bestemme. Retsligt er der bl.a. tale om "et nyt 'tykt' charter af rettigheder og pligter, der omfatter politisk, social og økonomisk ret" (s. 307). Politisk set er hovedpunktet: "Governance på flere niveauer og delt suverænitet" (s. 309). Økonomisk kosmopolitisme indeholder bl.a. etableringen af et "overførselssystem indenfor og mellem samfund" (s. 311), hvilket vil gøre en form for international skatteopkrævning nødvendig. På den ene side er der punkter som går på at reformere eksisterende institutioner eller påpege udviklinger som tydeligvis foregår, som f.eks. kulturel hybridisering. På den anden side er der forslag som er mere vidtrækkende og som vil kræver langt mere omfattende politisk kampe at virkeliggøre. Det hænger sammen med, at Held ser kosmopolitisme som såvel et moralsk som et politisk synspunkt knyttet til en bestemt analyse af tingenes tilstand.

Held har ikke udelukkende holdt sig til at behandle spørgsmålene om demokrati og globalisering i teoretiske og almene vendinger. Han har også benyttet sin position som intellektuel til at foreslå, at EU skal have en direkte valgt præsident. En ændring som skulle give en større inte- resse omkring hvad der sker på det overstatslige niveau og dermed være et skridt på vejen til en kosmopolitisk suverænitet. På trods af at jeg ikke tror, at Held har det endelige svar - teoretisk såvel som politisk - på hvordan man skal forstå og forholde sig til globaliseringen, er han værd at lytte til. Han kommer med spændende bud på hvilke politiske trusler og muligheder sam- og fremtiden indeholder. Der er uomtvisteligt tale om vigtige og presserende spørgsmål. Det er da også en debat, hvor mange stemmer forsøger at blive hørt. En af de stemmer det er værd at lytte til er David Helds. Det skal hilses velkomment at det nu er blevet muligt på dansk i dette gode og lettilgængelige udvalg.

Peter Bjorntoft 